\title{
Hegemonic Shifts: \\ The Latest from the Walls of Northern Ireland
}

\author{
Tony Crowley \\ University of Leeds, UK
}

Copyright (c) 2015 by Tony Crowley. This text may be archived and redistributed both in electronic form and in hard copy, provided that the author and journal are properly cited and no fee is charged for access.

\begin{abstract}
This essay considers the changes that have taken place in the murals of Northern Ireland over the past decade or so. It will be argued that although there have been important developments in the murals that reflect the consolidation of 'peace' during this period, the walls also tell a different story. It will be shown that, perhaps predictably, given the paralysis and stagnation that have characterised the power-sharing arrangements, and the disillusionment, cynicism and bitterness towards the political settlement which is now evident, a number of murals offer representations that indicate the growth of tendencies that present latent but real dangers.
\end{abstract}

Key Words. Northern Ireland, 2005-2015, Political developments, Hegemony.

Resumen. El ensayo considera los cambios que han tenido lugar en los murales de Irlanda del Norte en la última década más o menos. Se argumentará que si bien se han producido en los murales avances importantes que reflejan la consolidación de la 'paz' durante este período, las paredes también cuentan una historia diferente. Se verá que, tal vez como era previsible, dada la parálisis y estancamiento que han caracterizado los acuerdos de reparto de poder, y la desilusión, cinismo y amargura hacia una resolución política que ahora es evidente, una serie de murales ofrecen representaciones que indican el aumento de tendencias que evidencian peligros latentes pero reales.

Palabras clave. Irlanda del Norte, 2005-2015, acontecimientos políticos, hegemonía.

\section{Introduction}

In a searchable online archive that covers the development of the murals of Northern Ireland from 1979-the present (featuring some 3000 images, with a further 9000 to be catalogued), I have attempted to register a remarkable, durable, and often contentious cultural phenomenon. ${ }^{1}$ Namely, the ways in which walls in Northern Ireland have been used as sites of articulation and contestation, locations where political modalities can be asserted, violence threatened, history interpreted, identities expressed, and jokes made (to name but a few of the functions of the wall-texts that have appeared over the past thirty-five years or so). Underpinning the archive is the belief that the murals in their entirety constitute a complex, changing, fascinating body of public art that brings an added element to the understanding of the conflict in Northern Ireland and the 'peace' that has followed. Taken together, these materials provide an important record that renders significant insights into the complicated and strange history of Northern Ireland as it has passed from a state of war to the unstable and as yet precarious 'peace process'.

1. The 'Murals of Northern Ireland' collection is hosted by the Claremont Colleges Digital Library and can be found at: http://ccdl.libraries.claremont.edu/cdm/landingpage/collection/mni. 
The focus of this essay is on the changes that have taken place in the murals of Northern Ireland over the past decade or so (effectively since the 2006 St. Andrews Agreement), and more particularly the past five years. ${ }^{2}$ It will be argued that although there have been important developments in the murals that reflect the consolidation of 'peace' during this period, the walls also tell a different story. ${ }^{3}$ It will be shown that, perhaps predictably, given the paralysis and stagnation that have characterised the power-sharing/division of power arrangements, and the disillusionment, cynicism and bitterness towards the political settlement which is now evident, a number of murals offer representations that indicate the growth of tendencies that present latent but real dangers.

\section{The murals and their complexity}

I have written elsewhere about the evolution of the murals of Northern Ireland both in terms of form and function. ${ }^{4}$ From the simplest beginnings - a flag and a slogan for example (fig.1) - the murals have developed into lieux de mémoire, to use Pierre Nora's term, and now, significantly, form part of a burgeoning heritage industry that brings tourists to very specific parts of Belfast and Derry in particular (fig.2). ${ }^{5}$ The relatively recent growth of mural tourism has undoubtedly had an effect on the form and content of artwork on walls in particular locations. On one of the main routes into Republican West Belfast, for example, at the junction of Divis Street and Northumberland Street, the 'International Wall' has become the site of a number of murals that address not just issues local to Northern Ireland, but topics of wider social and political interest (fig.3).

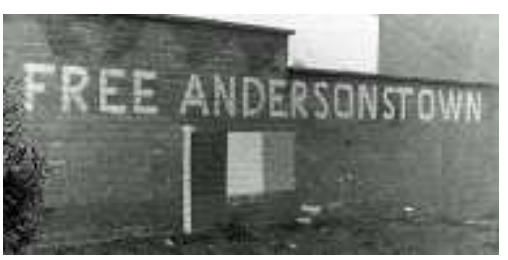

1. Free Andersonstown, Lenadoon Avenue, West Belfast, 1979

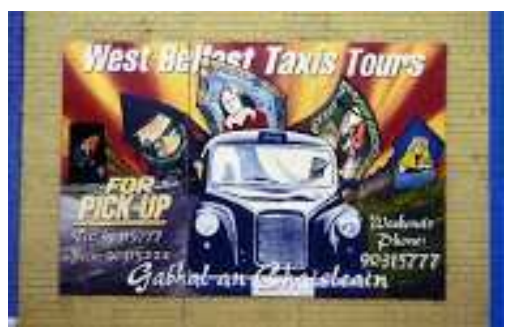

2. West Belfast Taxi Tours, Divis St., Falls, 2004

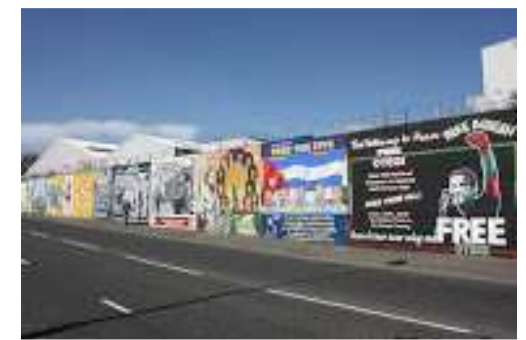

3. International Wall, Divis Street, 2014

2. The Belfast Agreement was signed in 1998, though its measures were in effect suspended until the Northern Ireland (St Andrews Agreement) Act of 2006 facilitated 'power-sharing' - which might better be described as the division of power - between Unionists and Nationalists/Republicans.

3. 'Peace' is a relative term. The Secretary of State for Northern Ireland recently informed parliament that 'dissident republican groups remain active in Northern Ireland' and noted that 'the threat continues to be suppressed as a result of successful operations by security and law enforcement agencies', but 'that there remains a high level of underlying terrorist activity and planning' (https://www.mi5.gov.uk/home/thethreats/terrorism/northern-ireland/republican-terrorist-groups.html). To reinforce the point, the Head of MI5 reported the disruption of more than 20 dissident Republican attacks during 2014

(http://www.belfasttelegraph.co.uk/news/local-national/northern-ireland/most-2014-dissident-attacks-stopped30894613.html). At a deeper level, sectarian violence continues to erupt in everyday life; reading the news reporting of The Belfast Telegraph for even a few days would cure anyone of the belief that 'peace' has broken out in Northern Ireland.

4. See 'The art of memory: the murals of Northern Ireland and the management of history', Field Day Journal of Irish Studies, 7, 2011 and 'Digitising the murals of Northern Ireland (1979-2013): Images and interpretation', Breac: A Digital Journal of Irish Studies, 2014.

5. Pierre Nora, 'Between Memory and History: Les Lieux de Mémoire', Representations26, (Special Issue: Memory and Counter-Memory), Spring 1989, pp. 7-24. 
While on Cupar Way, the Loyalist side of the Peace Line (fig.4) now features not just murals by local groups (fig.5),

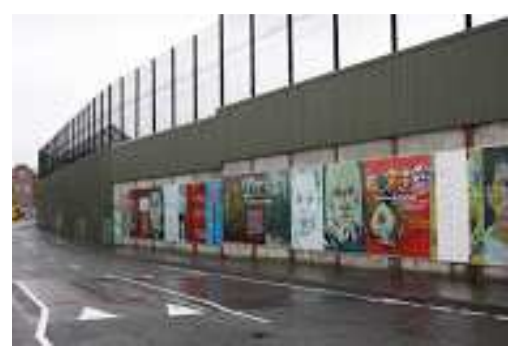

4. Cupar Way, Peace Line, Loyalist side, 2010

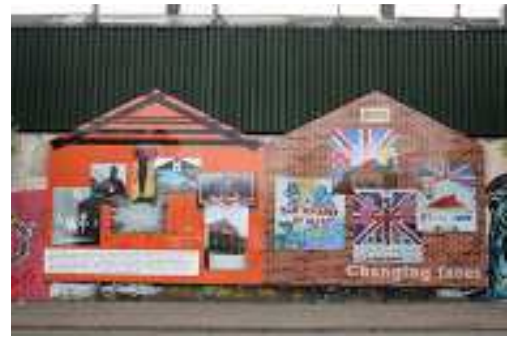

5 Changing Faces, Cupar Way, Peace Line, Loyalist side, 2010

but work by international artists - often in the form of tagging (fig.6), and graffiti by the multitudes of visitors brought by Belfast's numerous tourist-taxi firms (fig.7).

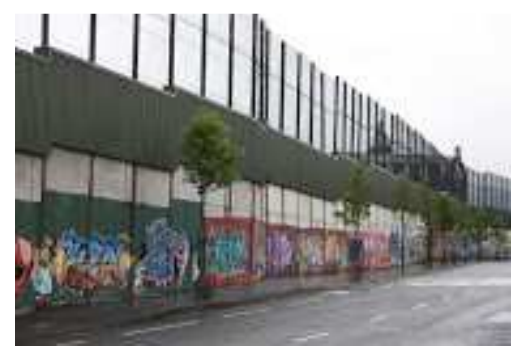

6 Tagging, Cupar Way, Peace Line, Loyalist side, 2010

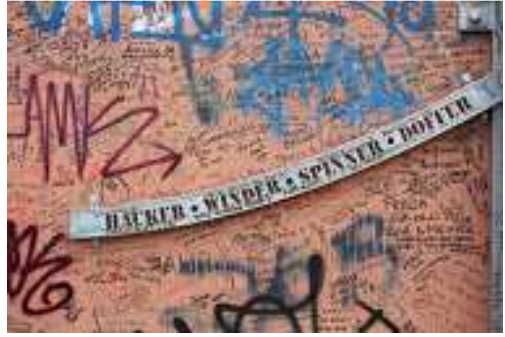

7 Graffiti, Cupar Way, Peace Line, Loyalist side, 2010

The social effect of the influx of visitors that the murals have brought to specific areas is unknown though probably relatively limited since most tourists effectively hit the murals and run - especially on the Loyalist side. But this new phenomenon certainly engenders somewhat incongruous encounters. In the summer of 2014, for example, while photographing on the Loyalist lower Shankill estate (once the home of the notorious paramilitary Johnny Adair and still largely under the influence of the Ulster Defence Association), I noticed a coach pull up. The vehicle, which bore the name of its owners and their location - County Monaghan (in the Irish Republic), was rapidly emptied of its passengers, who turned out to be Spanish teenagers on a day out from their English language school in Dublin. Quite what those teenagers made of the murals - a mix of paramilitary images (fig.8), State-sponsored local history (fig.9), and mythical allusion (fig.10), is unclear. But it was evident from the number of selfies taken, that one of the murals was a particular favourite amongst these visitors. It depicts Martin Luther

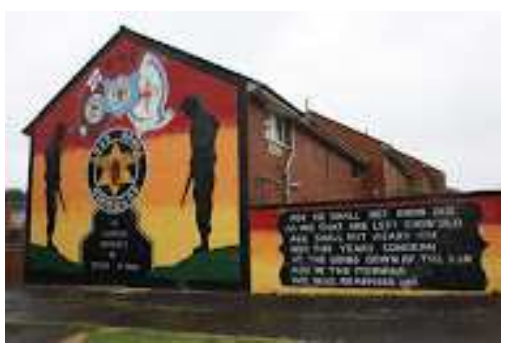

8. Paramilitary memorial, Hopewell Crescent, Lower Shankill, 2014

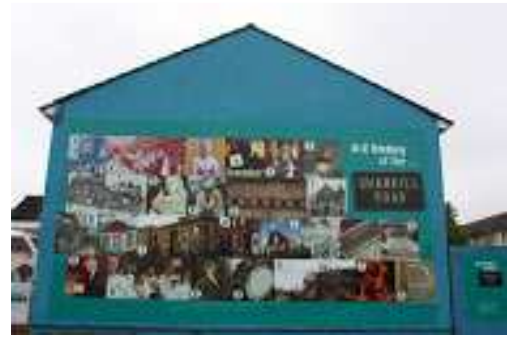

9. History of the Shankill, Boundary Way, Lower Shankill, 2014

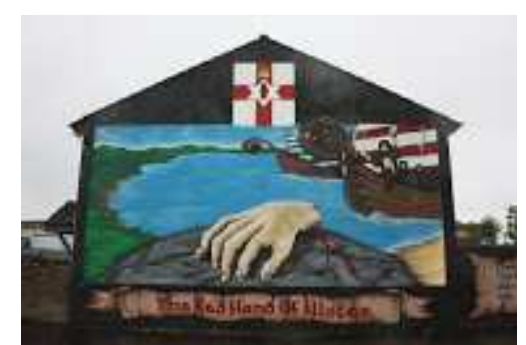

10. The Red Hand of Ulster, Boundary Way, Lower Shankill, 2014 
('Here I stand. I can do no other') at the Diet of Worms in 1521 (fig.11). Whatever else might be said about it, this was a complex cultural event: a coach registered in a country regarded as enemy territory by some Loyalists, delivered a crowd of English-language-learning teenagers, many of whom were presumably from (at least culturally) Catholic backgrounds, to an impoverished Loyalist heartland estate to sightsee its murals. The teenagers wandered freely around the area, taking photographs of themselves in front of the images, particularly one that represents one of the founding moments of Protestantism (fig.12). ${ }^{6}$ It is a scenario that would have been unimaginable in even the relatively recent past.

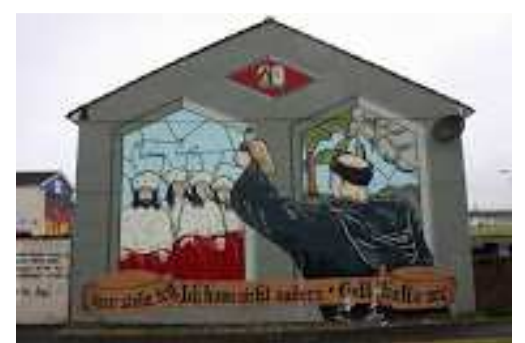

11. Martin Luther, Boundary Way, Lower Shankill, 2014

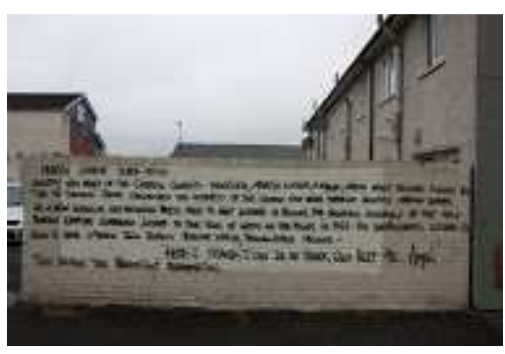

12. The Protestant Reformation, Boundary Way, Lower Shankill, 2014

For my purposes, what this event indicates is the intricacy of interpreting contemporary murals in terms of audience, design and function. But the historical and cultural complexity of the Northern Irish murals is hardly a new development, even if some of the circumstances of their production and reception are novel. Consider for example a mural which originally appeared on the New Lodge Road in 1996, which commemorates the experience of the Republican prison campaign during the war (fig.13). Painted after the declaration of the second IRA ceasefire, but before the signing of the Belfast Agreement, the mural consists of a number of images - some of which were re-circulations of iconic murals painted elsewhere in Belfast - and a brief analysis will demonstrate its historically allusive depth. At the top of the mural the slogan 'Free the POWs' appears, along with a green ribbon and 'Saoirse' ('Freedom') - the symbol of the campaign for the release of prisoners - together with a dove of peace. These images are superimposed on a

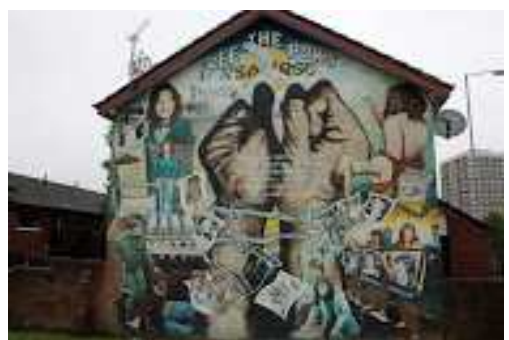

13. Saoirse, New Lodge Road, New Lodge, 2010 full moon, a reference to 'The Rising of the Moon' - the rebellion of the United Irishmen in 1798 and in this context possibly an allusion to an entry in Bobby Sands's prison diary ('the day will dawn when all the people of Ireland will have the desire for freedom to show. It is then we'll see the rising of the moon'). ${ }^{7}$ Clockwise from the top, there are representations of a Blanketman, a Republican prisoner taking part in the dirty protest, writing a Gaelic lesson on the prison wall ('Tá mé, Tá tú'), and another prisoner being strip-searched (these images were taken from a well-publicised photograph smuggled out of the Maze prison and a 1981 mural (fig. 14)). ${ }^{8}$

6. The teenagers were entirely undisturbed by the local residents and seemed to be greeted in a friendly if resigned manner, apart from the local small sweetshop owner who made them, to their evident bemusement, obey the same injunction that governs local children ('only two children allowed in the shop at any time'); like their Belfast peers, the Spanish kids were forced to queue in the rain outside.

7. Bobby Sands, diary entry, 17 March 1981, translated from the original Irish, http://www.bobbysandstrust.com/writings/prison-diary.

8. The photograph of the Republican prisoner on the dirty protest in the Maze is viewable at http://www.theguardian.com/film/2008/oct/19/northernireland. 


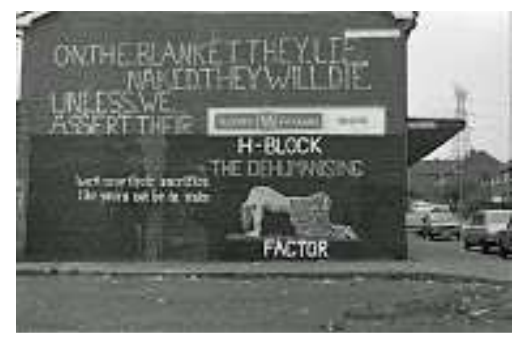

14. On the Blanket, Finaghy Road North, Belfast, 1981

Beneath these representations are a series of reproductions of a number of important Republican posters, some of which were either based on murals or featured on murals later (figs. 15, 16, 17). ${ }^{9}$

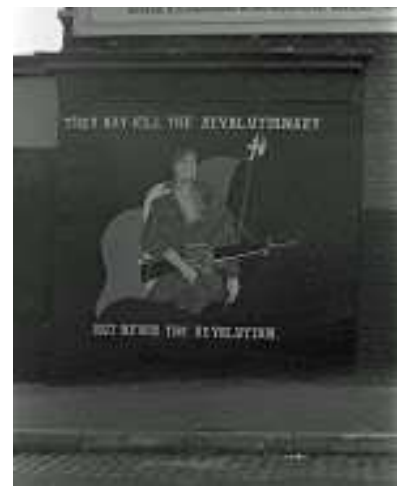

15. The revolutionary, Rockdale Street, Belfast, 1981

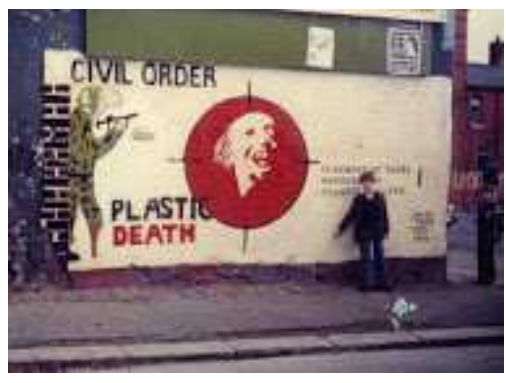

16. Plastic death, Whiterock Road, Belfast, 1982

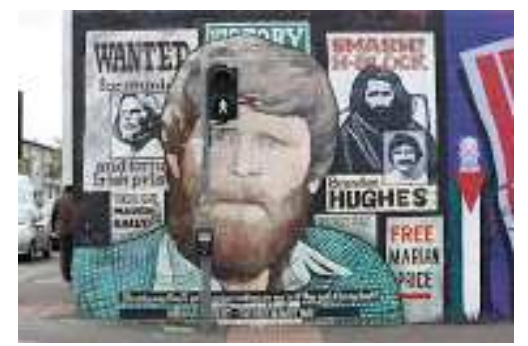

17. Wanted, International Wall, Divis Street, Belfast, 2012

Across the bottom of the mural, there are another three scenes taken from media images: a while line protest during the Hunger Strikes; women announcing the death of Bobby Sands in the traditional binlidding way; and a snatch squad of British soldiers. ${ }^{10}$ To the mid left of the mural there is an image of an anti-internment protest, with Long Kesh in the background, while above there are two representations of Mairéad Farrell, the Sinn Féin activist and IRA Volunteer killed while on active service in Gibraltar 1988. One is based on a photograph from within Armagh Prison where Farrell led Republican women prisoners on a blanket and dirty protest and Hunger Strike, the other is a still from the banned film 'Mother Ireland' (1998), made for Channel 4 and dropped because of the British Broadcasting Ban. ${ }^{11}$ Finally, the mural depicts Republican prisoners in a rooftop protest demanding repatriation to Northern Ireland (an image based on BBC news reports).

9. The posters themselves are references to historical texts used in the Republican campaign. As well as the wanted poster of Margaret Thatcher, there are posters that demand freedom for Róisín McAliskey and Pat McGeown; that ask for support for the Republican prisoner organisation Green Cross / Cumann Cabrach; that oppose censorship; that reference the brutal treatment of prisoners after the burning of Long Kesh in 1974; that appeal for the end of strip-searching in Armagh women's prison. Images of several of these posters are viewable at https://www.tumblr.com/search/irish\%20hunger\%20strike (Thatcher);

http://www.culturenorthernireland.org/features/heritage/troubled-images-posters-1-10 (Stop Strip Searches); http://www.anphoblacht.com/contents/24472 (Burning of Long Kesh).

10. It was common to see women dressed as prisoners on the blanket on Republican protests (see http://www.bobbysandstrust.com/multimedia/photos/nggallery/page/3).

11. The photograph of Farrell within the prison is viewable at http://womensmuseumofireland.ie/articles/thedirty-protests; for details of Mother Ireland, see http://bufvc.ac.uk/dvdfind/index.php/title/14461. 
Interpretation of this mural, which has now stood for nineteen years and which constitutes a minihistory of the Republican prison campaign, entails a considerable range of reference across a number of different popular cultural media - film, television, photography, and street posters. But there are other murals which evince a different type of historical complexity. Consider in this regard what might be termed 'the uses of Cú Chullain'. The image of this mythical hero of the Ulster Cycle of the Gaelic tradition has long featured in Irish Republican iconography, often in depictions of his death when, mortally struck, he tied himself to a stone to face his enemies and a raven landed on his wounded shoulder signalling his imminent death. Used as a a nationalist symbol during the Gaelic Revival (not least by Lady Gregory and W.B. Yeats), the epitome of this figuration is Oliver Sheppard's statue, 'The Dying Cu chulain' (1911), which now stands as a memorial to the 1916 Rising in the Dublin GPO. ${ }^{12}$ It is unsurprising therefore that representations of Cú Chullain have been deployed by Republicans from an early point in the development of their murals, as for example in an IRA memorial on Rossville Street in Derry in 1981 (fig.18). Such uses continue today and

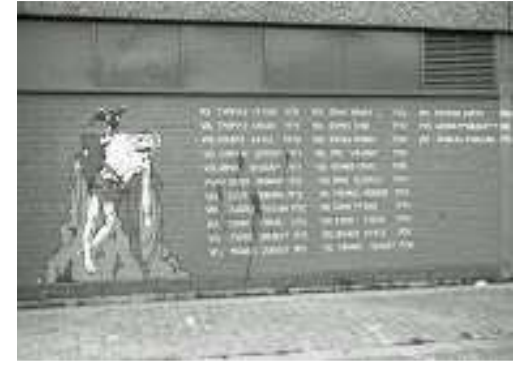

18. Derry CúChulainn, Rossville Street, Derry, 1981

can be seen in Republican memorials in Andersonstown (fig.19), Ballymurphy (fig.20), and a very recent mural in Poleglass (fig.21).

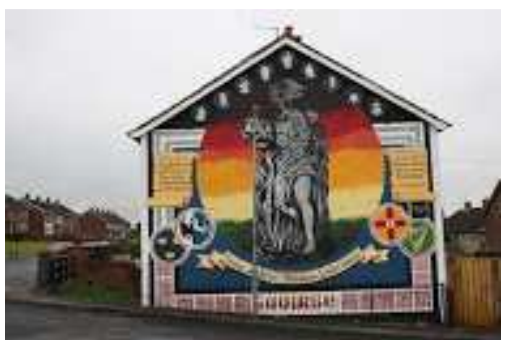

19. Lenadoon Cú Chulainn, Lenadoon Avenue, Belfast, 2010

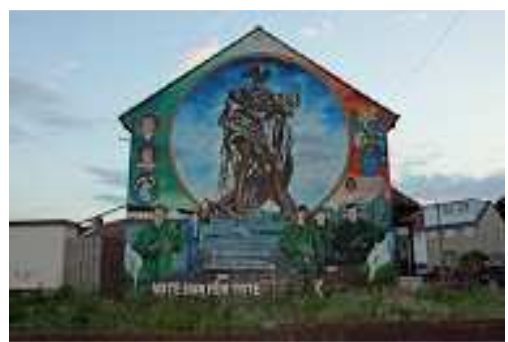

20. Ballymurphy Cú Chulainn, Glenalina Road, Belfast, 2010

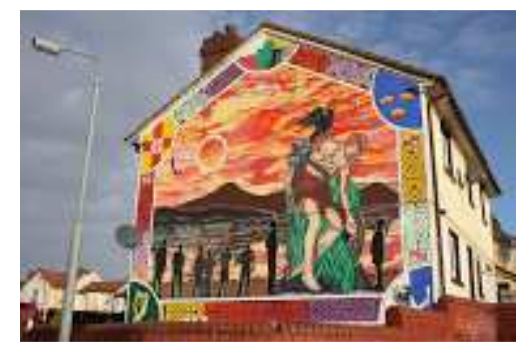

21. Poleglass Cú Chulainn, Glenbawn Avenue, Belfast, 2014

Strikingly, however, Cú Chulainn is also used in murals commissioned by Loyalists in which the theme remains the same, yet the political and historical message is reversed. Here for example is a UDA/UFF memorial mural on the Highfield estate (overlooking Ballymurphy) (fig.22), while another, atypically, depicts Cú Chulainn in victorious pose on a wall in the Lower Shankill estate (fig.23). Such duality - Republican and Loyalist hero - is, at first sight at least, puzzling and can only be explained

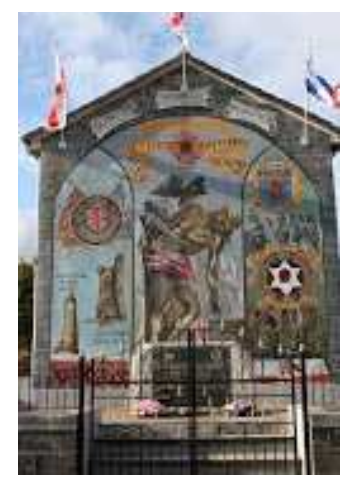

22. Highfield Cú Chulainn, High Green, Belfast, 2000

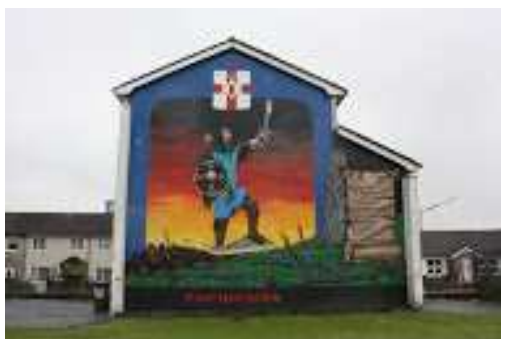

23. Lower Shankill Cú Chulainn, Boundary Way, Belfast, 2009

12. See http://www.timelessmyths.com/celtic/gallery/deadhound.gif 
with reference to the Gaelic myths in which Cú Chulainn appears. For while Republican representations valorise him as a heroic Gaelic warrior who dies a glorious death (despatching his enemies even in his final moments), Loyalist representations focus instead on his role as a defender of Ulster against the threat from Connacht (a task which he undertakes brutally and successfully in Táin Bó Cúailnge). It is this perhaps that explains not only the figure of Cú Chulainn triumphant in the Lower Shankill text, but also the anachronistic declaration of identity politics that accompanies it (fig.24). ${ }^{13}$

\section{Re-historicising the past}

As is clear, interpreting murals can be a complicated business since like any other cultural text they are both of and in the history that produced them, reflections of it as well as interventions in it. In that regard, one longstanding mural reminds us of an important lesson: that representations, particularly representations of the past, matter (fig.25). This is hardly news in Northern Ireland of course since key moments in history have often been commemorated, not least on the walls. Examples include the

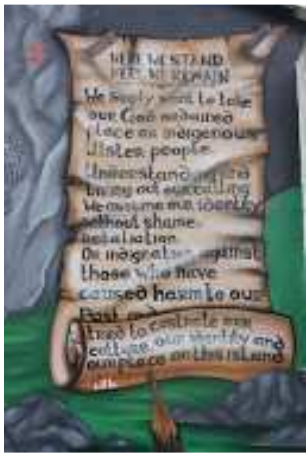

24. Lower Shankill Cú Chulainn, Boundary Way, Belfast, 2009

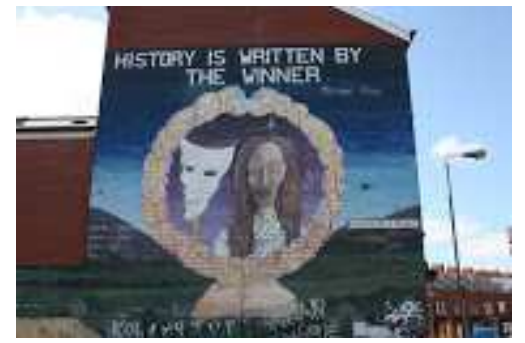

25. History is written by the winner, Oakman Street, Beechmount, Belfast, 2014

Flight of the Earls (1607) (fig.26), the triumph of William at the Battle of the Boyne (1690) (fig.27), and variations on 1916 (both the Easter Rising and the Somme) (figs. 28, 29).

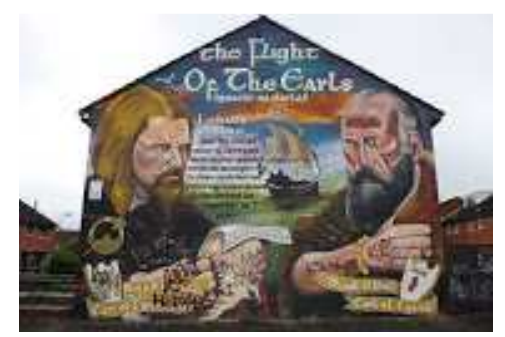

26. Flight of the Earls, Ardoyne Avenue, Ardoyne, Belfast, 2010

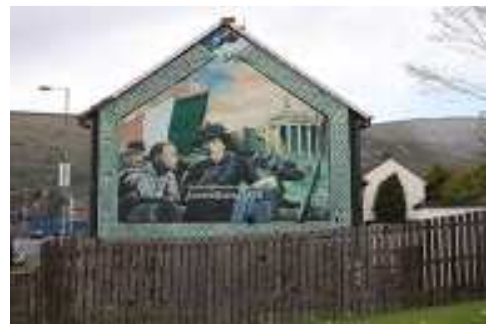

28. Easter 1916, Whiterock Road, Ballymurphy, Belfast, 2001

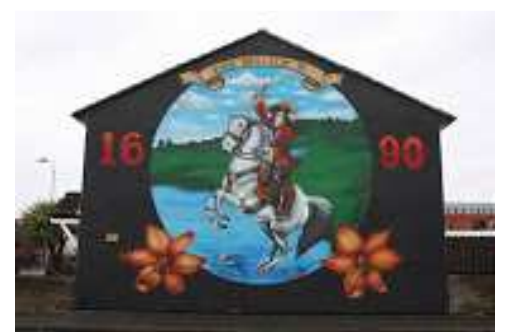

27. King William, Shankill Parade, Lower Shankill, Belfast, 2008

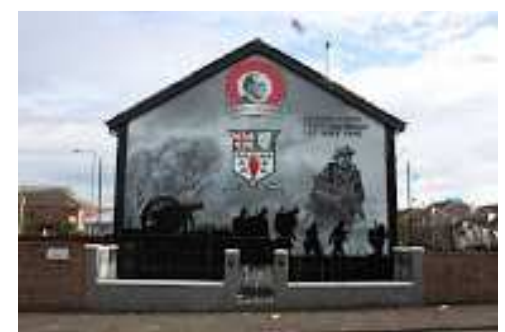

29. Thiepval Wood, Northland Street (Thiepval Street), Shankill, 2012

13. Bill Rolston, the pioneer in recording and analysing the murals, has commented that the Loyalist use of Cú Chulainn is connected to the attempt to create a foundational myth for Ulster that depicts Cú Chulainn as one of the Cruithin (Picts), a pre-Celtic people who occupied the North of Ireland before the Gaels. In this mythification, Cú Chulainn becomes the first defender of Ulster and thus the forebear of contemporary Loyalism. See Bill Rolston, Drawing Support 2 Murals of War and Peace (Belfast: Beyond the Pale, 1998, p.iii). 
But I would argue that over the past decade, perhaps even less than that, there have been significant developments in mural work in terms of re-historicising. These have taken different forms and they represent distinct tendencies, but as is always the case with the walls, they articulate and play a role in constructing larger social trends and patterns.

One important aspect of this process has been the intervention of the State itself (either directly or at arms-length) in the commissioning and production of murals in Northern Ireland over the past decade. ${ }^{14}$ Primarily financed through the 'Re-imaging Communities' scheme, this has also taken the form of State sponsorship of local community groups or indeed specific projects through a variety of governmental and non-governmental agencies. ${ }^{15}$ On occasion the new murals were commissioned to replace paramilitary texts (figs. 30, 31)

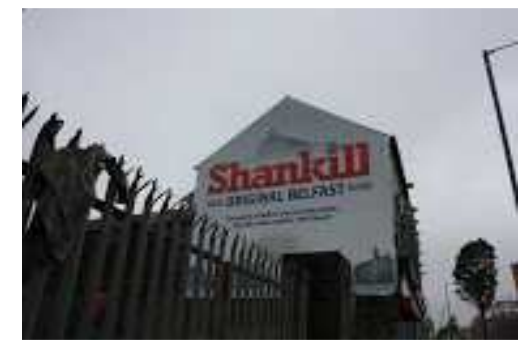

30. Shankill Original Belfast, Shankill Road, Belfast, 2009

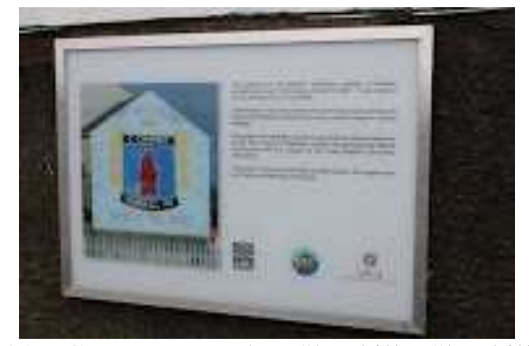

31. Gateway to the Shankill, Shankill Road, Belfast, 2009

though elsewhere, they were simply additions (figs. 32, 33).

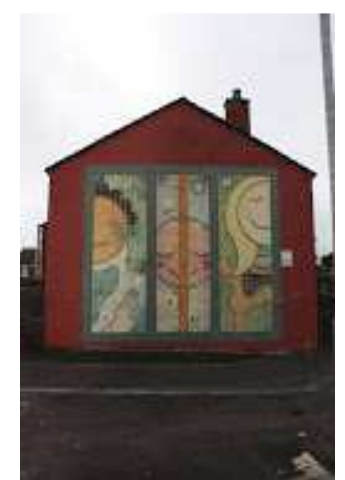

32. Kids mural, Brompton Park, Ardoyne, Belfast, 2009.

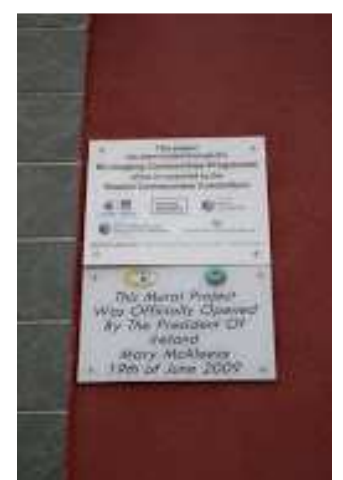

33. Plaque to Kids mural, Brompton Park, Ardoyne, Belfast, 2009

Considered from one perspective, this can be viewed as a tardy official recognition of the significance of the murals, and of the fact that they won't be disappearing anytime soon. From another standpoint, it can be interpreted as an attempt by the State to engineer safe representations of the past, or of apolitical topics.

The evidence suggests that this is a somewhat ambivalent development and one that is connected to other changes. Recently, for example, a great deal of material related to 'local history' has appeared on the walls, particularly - though not only - in Loyalist areas (indeed 'local history' is one of the few growth industries in Northern Ireland). And much of this work is interestingly inflected, particularly in

14. I have discussed the State's role in the murals at greater length in 'The art of memory' (see note one above).

15. Organisations through which the financing takes place include, amongst others: The Arts Council; the Department for Social Development; the Office of the First Minister and Deputy First Minister; the International Fund for Ireland; the Housing Executive; and the National Lottery. 
terms of the representation of class and gender. Consider for example a set of laminated murals - 'The Thread of History' - that have appeared on the Donegall Road, between the Loyalist areas of the Village and Sandy Row (fig.34). As well as significant historical moments for this community - the sinking of The Titanic, the Somme, the Belfast Blitz - the wall also presents feminist images featuring Ulster suffragettes (fig.35), a declaration of gender equality (fig.36), and women weaver poets (fig.37).

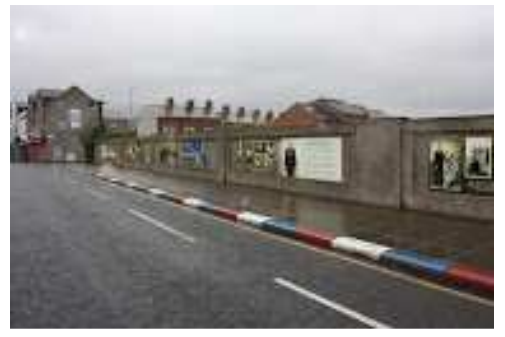

34. Local History, Donegall Road, South Belfast, 2014

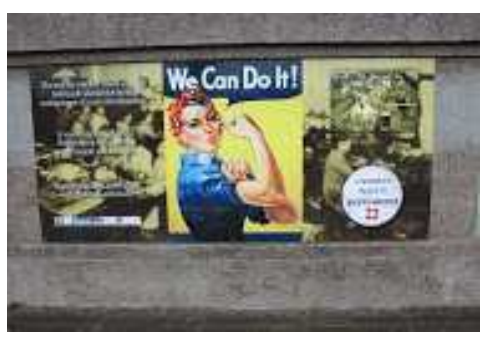

36. A Woman's Place is Everywhere, Donegall Road, South Belfast, 2014

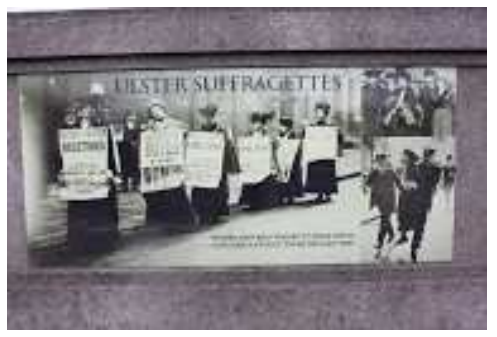

35. Ulster Suffragettes, Donegall Road, South Belfast, 2014

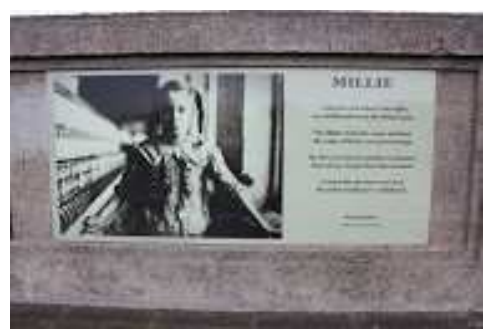

37. Woman Weaver Poet, Donegall Road, South Belfast, 2014

In addition reference is made to the area's class profile with images of male and female workers (including a rather incongruous, and unacknowledged, quote from Bill Clinton on the need for work) (figs.38, 39).

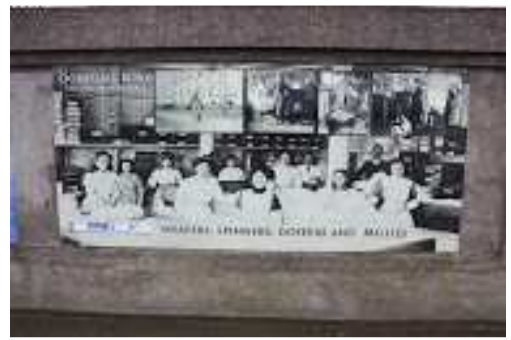

38. The Thread of History, Donegall Road, South Belfast, 2014

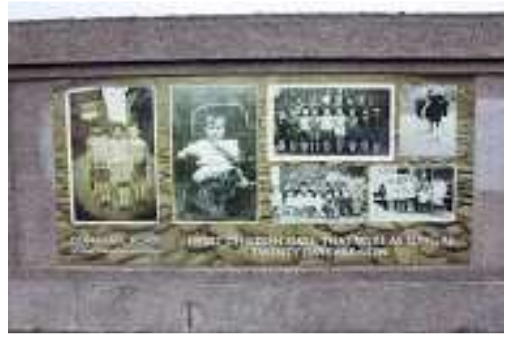

39. Pathway through Childhood, Donegall Road, South Belfast, 2014

These are progressive images, and their appearance in this location is striking, not least given that Loyalist working-class areas are (often in caricatured manner) associated with reactionary social attitudes. And yet it is important to note that it would be impossible to deduce from many of these representations (figs. 40,41 ) that the local history that they depict took place in a sectarian, divided

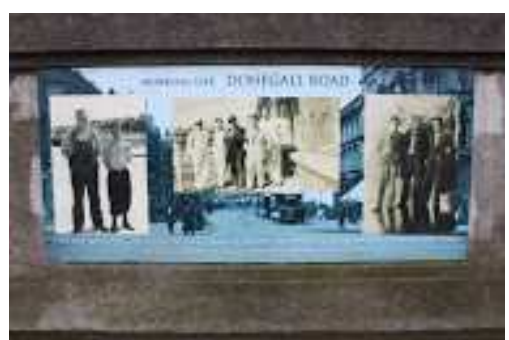

40. Working Life, Donegall Road, South Belfast, 2014

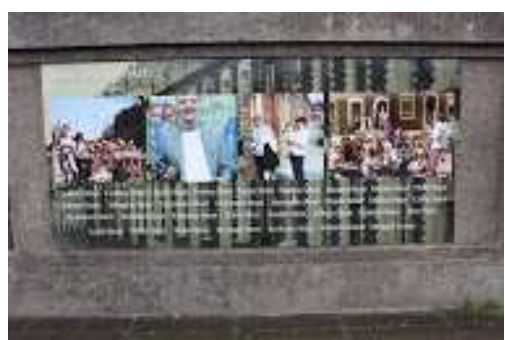

41. Streets of Dreams, Donegall Road, South Belfast, 2014 
society in which one section of the community suffered discrimination in employment, jobs and housing. Sometimes, it could be argued, local history can be a little too local.

A further trend in the process of re-historicising can be noted in the appearance of murals that signal an imperative to represent not just key foundational moments like 1690 or 1916 (the Uprising and the Somme), but perspectives on the more recent past. Two nationalist/Republican murals can illustrate one aspect of this shift. The first, on Divis Street, advertising 'political tours' by Coiste, the Republican ex-prisoners association, depicts the 1964 Tricolour event in which the flying of an Irish flag in an election office in this precise location caused Unionist uproar (it was one of the early significant public appearances of Ian Paisley), the confiscation of the flag by the police - twice - and a riot in response (fig.42). The mural drives home the contrast between 1964 and the present and underlines the message: all (flags) are welcome on the Falls Road these days. Sited next to one of the most extensive sections of the Peace Line, the second mural represents the burning out of nationalist Bombay Street (one of the first streets to suffer this fate) in August 1969. A montage of mock-up and photographs, and dedicated to Fiann Gerald McAuley (a 15 year old Republican killed by a Loyalist sniper while clearing the area), the mural again asserts a clear lesson: 'Never Again' (fig.43).

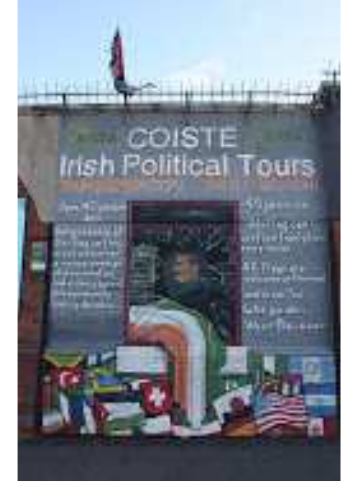

42. Coiste, Divis Street, West Belfast, 2010

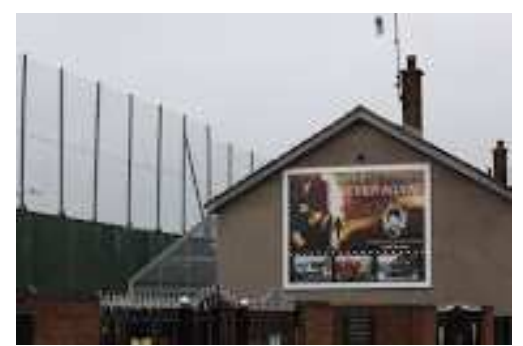

43. Drummer Boy, Hopewell Avenue, Lower Shankill, Belfast, 2010

And yet while these are important examples of Republican framing of the early Troubles, they are hardly unfamiliar in terms of the established historical narrative. A more interesting development, perhaps, is the way in which Loyalists have also started to represent this period of history from their perspective. One example is 'Summer of 69', a mural that appeared on the Lower Shankill estate in 2009, which portrays two Loyalist boys - a drummer and a baton-carrier - standing in a scene of dereliction (fig.44). This is a curious image, since it is both ambiguous (the dereliction to the left of the mural looks like a traditional 11th July bonfire) and apparently anachronistic (the terraced street in the background, with its boarded windows and doors, seems to reflect the effects of the destruction brought to

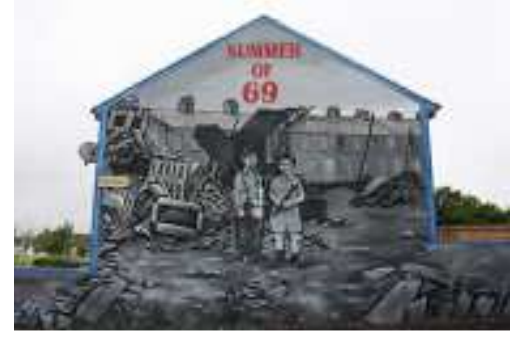

44. Never Again, Bombay Street, Clonard, West Belfast, 2006 this area by Belfast's contemporary planners rather than communal strife). Despite this, however, the implication appears to be that for the Unionist/Loyalist community, the summer of 1969 was as traumatic as it was for its nationalist/Republican neighbours, at least in terms of housing. Such an interpretation is not quite supported by the recorded history of the period, yet this is nonetheless a significant attempt at re-historicising events that have previously borne only one interpretation or been seen from one perspective. ${ }^{16}$

16. While one estimate calculates that $83 \%$ of buildings destroyed in the August 1969 rioting in Belfast were owned by Catholics and 1,505 Catholic families were forced to flee their homes, it is also the case that 315 Protestant families were similarly affected. See Tim Pat Coogan, The Troubles (London: Hutchinson, 1995, p.90). 
Another example in this regard is a mural in Loyalist East Belfast; originally composed in 2006 and re-figured in 2014, this work tells the 'Untold Story' of Protestant refugees fleeing to Liverpool in August 1971 (figs.45, 46).

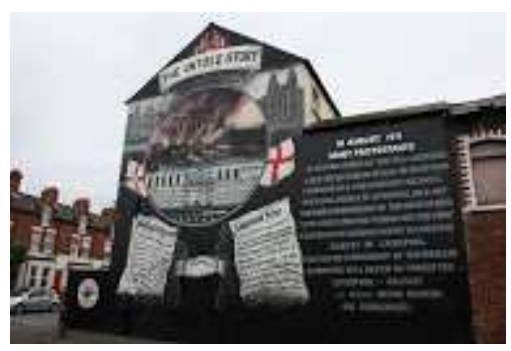

45. Untold Story (1), Canada Street, East Belfast, 2006

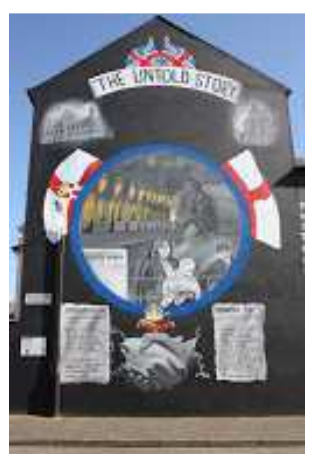

46. Untold Story (2), Canada Street, East Belfast, 2014

Again, the historical record does not quite bear out the claim made in the mural, but to the charge that such representations are mere myth-making (for its own part, the Coiste mural omits to mention any Republican involvement in the violence 'lasting decades'), it is worth noting that such texts seem to demonstrate a desire amongst specific elements of working-class Loyalism to engage in public debate and to shape an understanding of history according to its own viewpoint. ${ }^{17}$ In one sense this is hardly surprising since the importance of the contest over recent history is one that all sides evidently recognise, but given the historical failure of working-class Loyalism to gain formal political representation, this is a significant development and one that continues to play out on the walls.

\section{Peace, paint and progress?}

Though a visitor to Republican or Loyalist districts today might be surprised to learn it, a general clean-up took place in these areas in the decade or so after the Belfast Agreement and a considerable amount of (mostly political) graffiti was erased and walls painted over. And part of this new approach entailed a shift away from conflict-related murals in what might be called front-line areas (particularly the interfaces). Needless to say, given that they were involved in putting many of those murals up in the first place, this process has often included members of (ex-) paramilitary organisations, not least because (contrary to the now almost standard cliché that specific murals changed 'as a result of discussions between paramilitaries and the local community'), the (ex-) paramilitaries and their representatives play a significant role in the community and indeed usually belong to it. In any case, there are many examples of images that were significantly re-figured to reflect the developing historical situation. Thus the paramilitary (UDA) mural that 'welcomed' visitors to 'Loyalist Tiger's Bay' (fig.47) was replaced by one proclaiming 'Community Pride Culture' (fig.48).

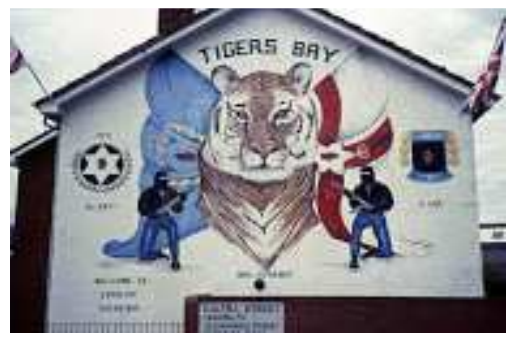

47. Tigers Bay (1), Cultra Street, Tigers Bay, Belfast, 2000

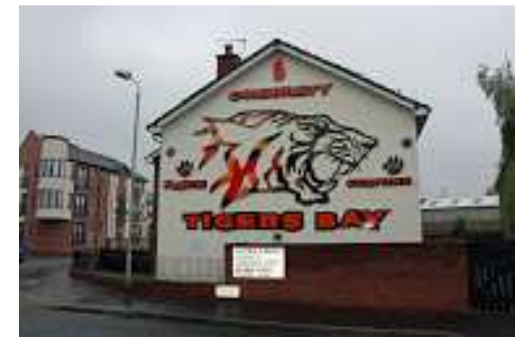

48. Tigers Bay (2), Cultra Street, Tigers bay, Belfast, 2009

17. Though there was large scale civil unrest and rioting after the introduction of internment in 1971, there is little evidence that nationalists or Republicans engaged in attacks against Loyalist areas. In the summer of $1971 \%$ 
In Sandy Row, the balaclava-clad UFF gunman adorning the admonitory 'You are Now Entering Loyalist Sandy Row' mural - a parodic allusion to the 'You are now entering Free Derry' slogan on the Free Derry wall (fig.49) - has been superseded by a sophisticated representation of King William of Orange, complete with the detail of the multicultural nature of his forces ('Danish, English, Dutch, French Huguenots, Prussian, Scots, Irish, Swiss, Polish, Italian, Norwegian’) (fig.50).

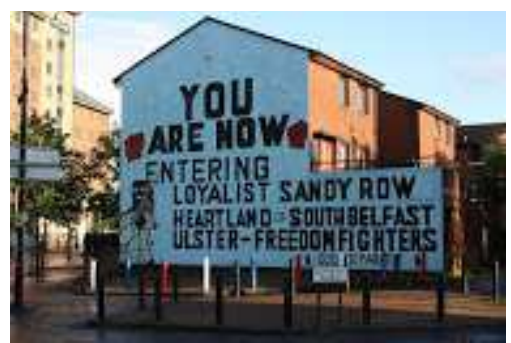

49. You Are Now Entering, Sandy Row, South Belfast, 2011

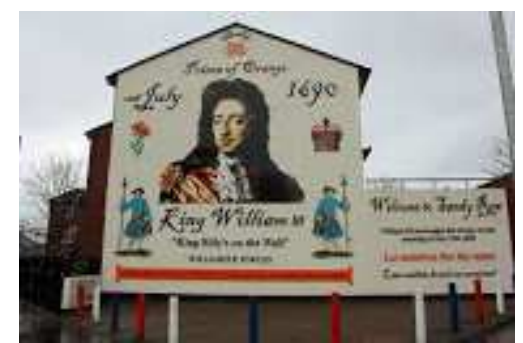

50. King Billy's On The Wall, SandyRow, South Belfast, 2014

And on the Lower Shankill estate, the mural that eulogised Oliver Cromwell's anti-Catholic sentiments (fig.51) has been supplanted by a sculpture - 'Remembrance Respect Resolution' (fig.52).

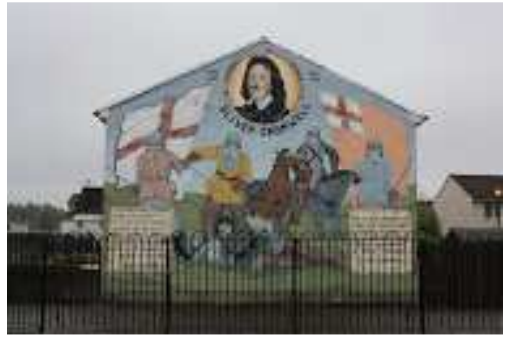

51. Cromwell, Shankill Parade, Lower Shankill, Belfast, 2010

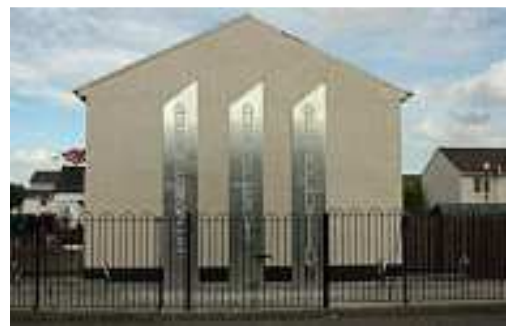

52. Remembrance Respect Resolution, Shankill Parade, Lower Shankill, Belfast, 2100

Something similar has been taking place on the Republican side too. Thus on Estoril Park in the upper Ardoyne, a mural commemorating the sectarian bitterness of the Holy Cross dispute (fig.53) has been replaced by one that celebrates the local community (even though the message of the earlier work is retained at the top of the image) (fig.54).

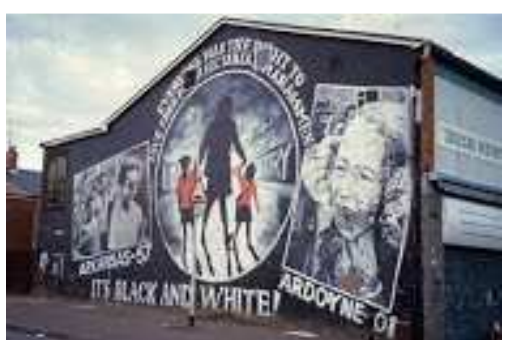

53. Black and White, Estoril Park, Ardoyne, Belfast, 2006

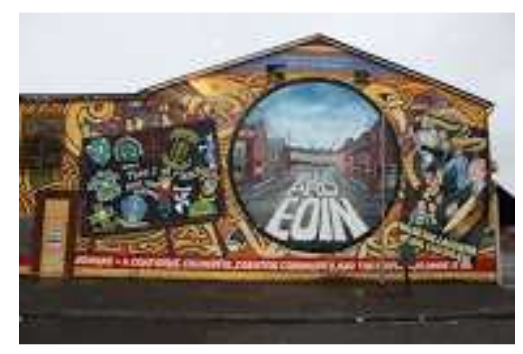

54. Ardoyne Community, Estoril Park, Ardoyne, Belfast, 2010

On Brittons Parade, off the Whiterock Road, a mural painted to commemorate the life of veteran Republican Joe Cahill, featuring an image of the IRA press conference he chaired locally after the

$\%$ supporters of the Orange Lodge in Liverpool did indeed offer shelter and respite from the general chaos and disturbance of the time to parties of women and children, though the total numbers were less than one thousand and for short periods of time. See The Liverpool Echo, August $28^{\text {th }}, 1971$. 
introduction of Internment in 1971 (fig.55), was changed for one that celebrates the inauguration of 'the Joe Cahill Perpetual Cup' (a trophy for Gaelic games) (fig.56).

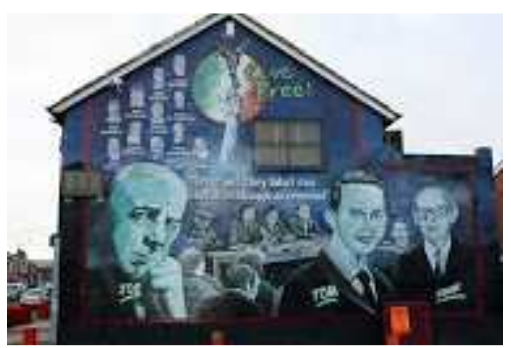

55. Joe Cahill, Brittons Parade, West Belfast, 2014

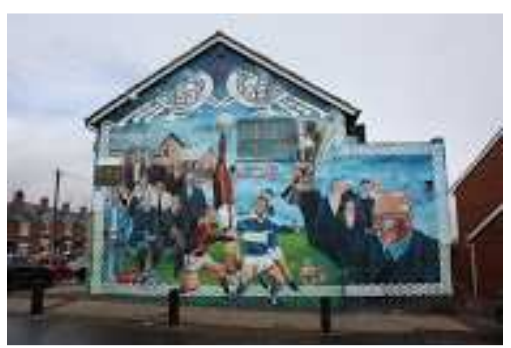

56. Joe Cahill, Brittons Parade, West Belfast, 2006

And in Gerry Adams's home turf of Ballymurphy, a mural representing four IRA men resting up at a safe house (fig.57) has been displaced by one featuring many of the same figures, now dedicated to the area's 'working-class heroes' (fig.58).

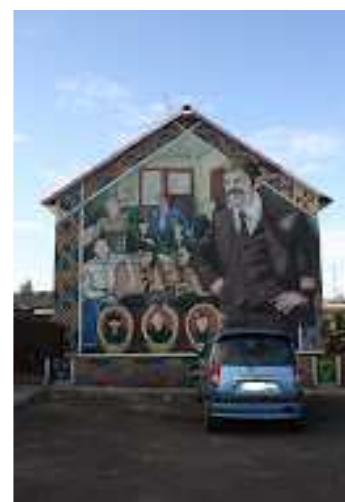

57. Safe House, Ballymurphy Crescent, Ballymurphy, Belfast, 2008

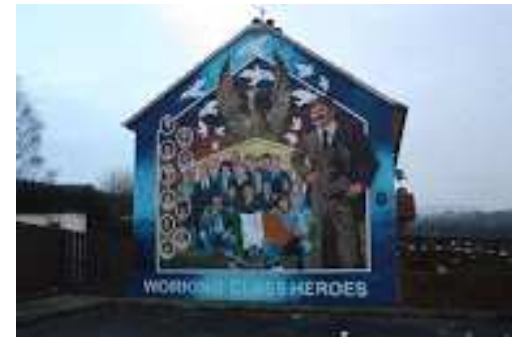

58. Working Class Heroes, Ballymurphy Crescent, Ballymurphy, Belfast, 2014

Such changes notwithstanding, there is one theme on the Republican side that, as yet, remains sacrosanct. The 1981 Hunger Strike continues to be revisited in various ways, including an annual update at a site opposite Bobby Sands's Twinbrook home (fig.59), and a recent and more controversial revision to a memorial for Kieran Doherty (controversial on the basis that it includes a depiction of an IRA firing party) (fig.60).

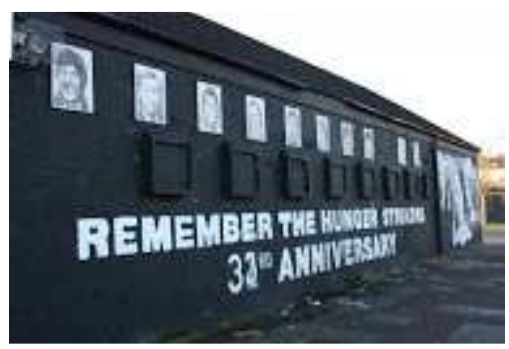

59. Memory update, Jasmine End, Twinbrook, Belfast, 2014

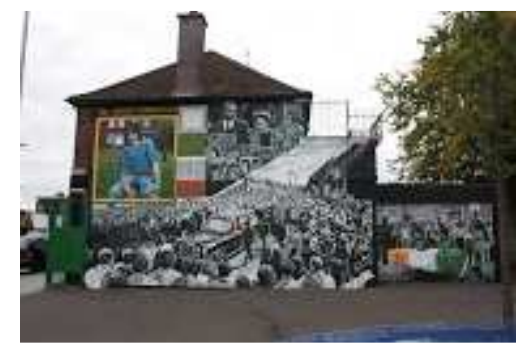

60. Kieran Doherty, Slemish Way, Andersonstown, Belfast, 2014

It is clear then that there has been a co-ordinated attempt in the recent past to replace a number of murals that featured violence by the commissioning of new work. Though it should always be remembered that these new texts are themselves likely to be coded in ways that are easily decipherable in the semiotically-sensitive context of Northern Ireland. Representations of the signing of the Ulster 
Covenant and the glorious founding of the UVF in 1912-13 (fig.61), for example, or the centenary of the venerable birth of Cumann na Mbanin 1914 (fig.62), carry their own political and historical message, as do murals, memorials and plaques dedicated to commemorating individual Republican or Loyalist paramilitaries.

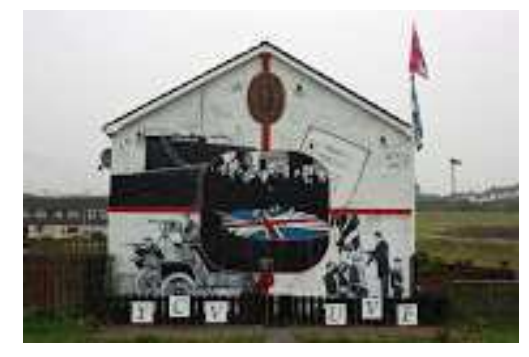

61. Covenant and UVF, Forthill Drive, Ballyduff, Newtownabbey, 2013

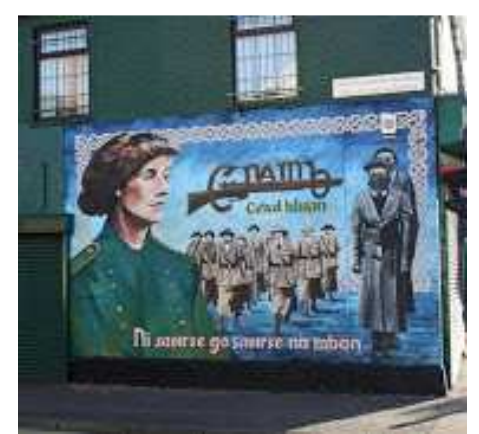

62. Cumann na Mban, Beechmount Avenue, Belfast, 2014

On the whole, however, it is fair to say that a great deal of graffiti has been erased, a good number of murals have been taken down, and many more, of a different nature, have been painted. There has been an effort, then, in very specific areas, to eradicate at least the everyday images of the nightmare of the past from the minds of the living.

If that were the whole story, then this article would tell a tale of paint, peace, and progress. But in fact, I would argue that over the past five years or so, a different story has been emerging on the walls, one that more accurately reflects the realities of the situation on the ground. One of the first signs of this new development was the appearance of two Loyalist paramilitary murals on the Newtownards Road in 2011, one of which was a re-creation of an image that had been sited on nearby Mersey Street in 1996 (figs 63, 64).

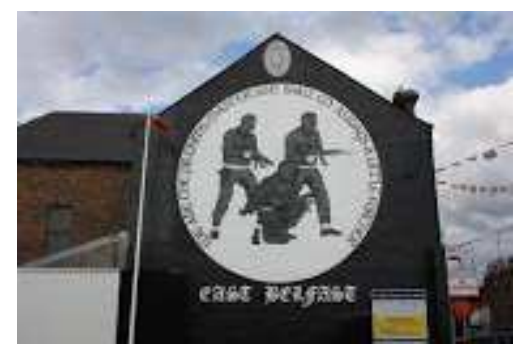

63. Pilgrims, Dee Street/Newtownards Road, East Belfast, 2011

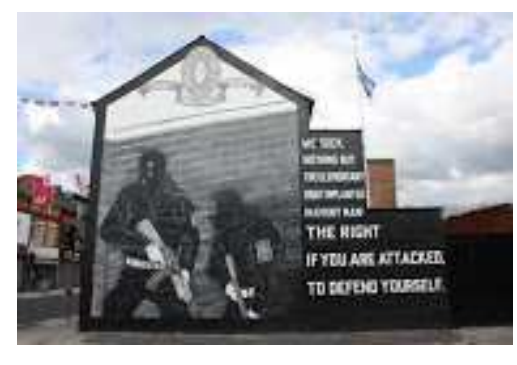

64. The Elementary Right, Dee StreetNewtownards Road, East Belfast, 2011

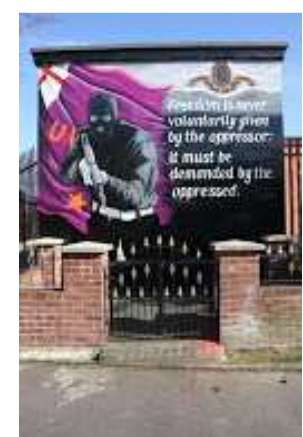

65. Demanding Freedom, Inverary Court, Sydenham, Belfast, 2013

Both murals represented heavily armed UVF Volunteers, as did another that replaced a figuration of the footballer George Best in the Sydenham area in 2013 (fig 65). Significantly, the reaction of the media and commentariat to these events was marked by outrage and condemnation. ${ }^{18}$ But in actuality, although the appearance of these particular murals may have local explanations (including tensions within and between different factions of Loyalism), they are hardly atypical of the general pattern of what has been developing in recent years as the stagnation and near-breakdown of the 'peace process' and its attendant political settlement has taken its toll. In fact, away from the tourist mural trail (which follows very specific routes), in the back streets and out in the estates, there are very different images to be found than those presented on the bus and taxi heritage tours. In those other places, where tourists don't wander, there are increasing numbers of murals that reflect a hardening of attitudes, a

18. For the general tenor of the reaction, see the coverage in the Belfast Telegraph at http://www.belfasttelegraph.co.uk/ news/northern-ireland/loyalist-murals-return-to-east-belfast-and-few-welcome-them-28616810.html 
reinforcement of sectarian division, and bitterness and disillusion with the 'post-conflict' situation. There the murals are not geared towards visitors or an international audience; they function instead as reminders (which are always at one and the same time promises) of the possibility of violence.

Of course such murals vary both in terms of political allegiance but also, as noted above, in relation to local factors. On the Loyalist side, many of these murals (though not all) are linked to the UVF. Some images are simply versions of older figurations that have been restored and/or renewed, as with the UVF murals on Castlereagh Road (fig.66) and Ravenhill Road (fig.67) in East Belfast, or the UDA/UFF murals on Castlemara Drive, Carrickfergus (fig.68) and Ballyree Drive (fig.69) on Bangor's Bloomfield estate.

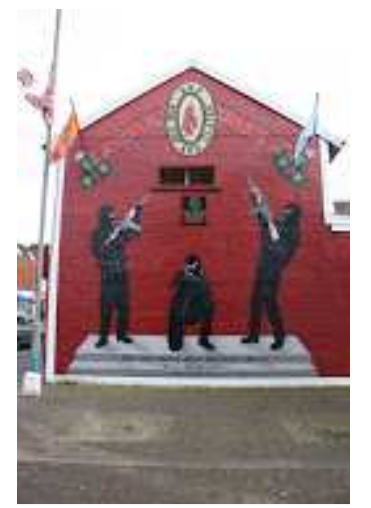

66. UVF, Castlereagh Road, East Belfast, 2014

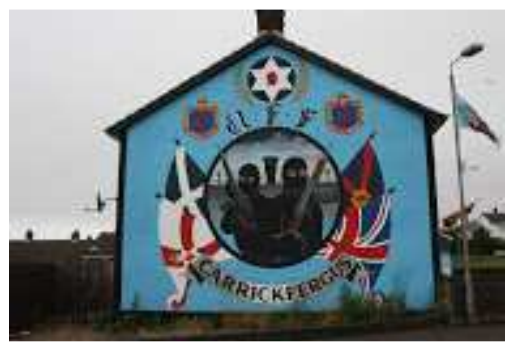

68. UFF, Castlemara Drive, Carrickfergus, 2013

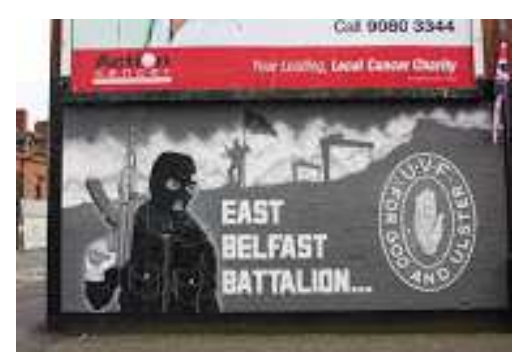

67. East Belfast Battalion, Ravenhill Road, East Belfast, 2014

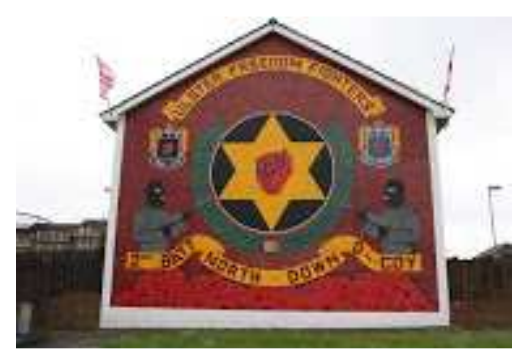

69. UFF, Ballyree Drive, Bloomfield Estate, Bangor, 2013

Others, however, have clearly been painted more recently, often to coincide with the centenary of the UVF (though they pointedly feature contemporary rather than early twentieth century paramilitary figures). Examples include those at Blenheim Drive (fig.70) and Shackleton Walk (fig.71) on the West Winds estate, Newtownards, and a very recent Red Hand Commando mural on the Bloomfield estate (fig.72).

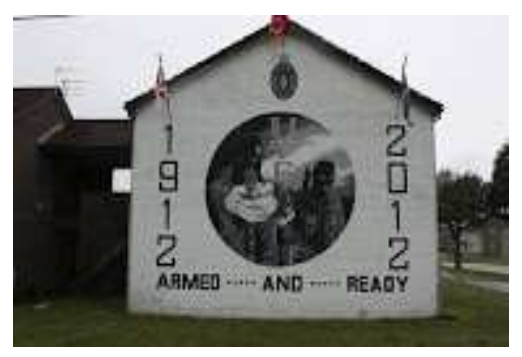

70. UVF Centenary, Blenheim Drive, West Winds Estate, Newtownards, 2012

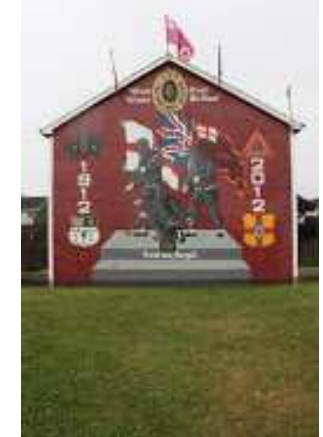

71. Lest We Forget, Shackleton Walk, West Winds Estate, Newtownards, 2012

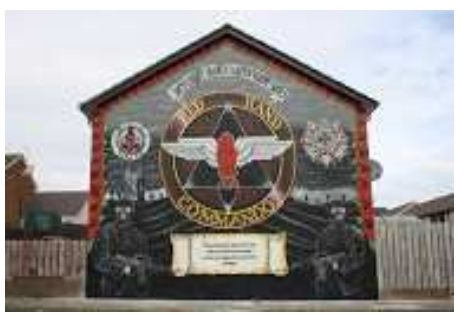

72. Red Hand Comando, Ballyminetragh Gardens, Bloomfield Estate, Bangor, 2014 
If these Loyalist images offer little difficulty in terms of understanding, murals on the Republican side are more complex given the political domination of Sinn Féin and the fragmentary nature of the internal opposition to it. Thus some images represent perfectly legitimate dissident Republicanism, and their anti-Sinn Féin stance is often implicit and thus in need of interpretation. For example, from one perspective, a mural in the 'The People's Gallery' in the Bogside gives recognition to the IRA men and women who took part in the Blanket protest and the Hunger-Strikes, and includes a portrait of Raymond McCartney, a Derry native and now Sinn Féin MLA (fig.73). ${ }^{19}$

But although several of the Bogside murals are in need of restoration, this work is unique in that it has been deliberately vandalised (paint bombed) with the aim of obliterating the representation of McCartney (and thus by extension that of Sinn Féin itself). Likewise, though a mural on Berwick Road in Ardoyne commissioned by the Republican Network for Unity does not mention Sinn Féin (fig.74), two elements of the work are implicitly critical of the party. The first is the declaration that the P.S.N.I (Police Service of Northern Ireland) is 'Not Welcome in Ardoyne' - a rejoinder to Sinn Féin's decision to join the 'Policing Board' in 2007 (thereby recognising the legitimacy of the police service). The second is the use of a quote from Mairéad Farrell, an iconic figure in the IRA (and sometime Sinn Féin member) (fig.75), offering a socialist Republican critique of the British presence in Ireland - a rebuke to Sinn Féin's participation in a Northern Ireland Assembly that functions within the Union.

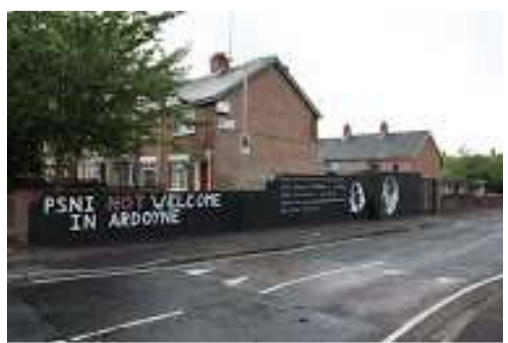

74. PSNI Not Welcome, Berwick Road, Ardoyne, 2013

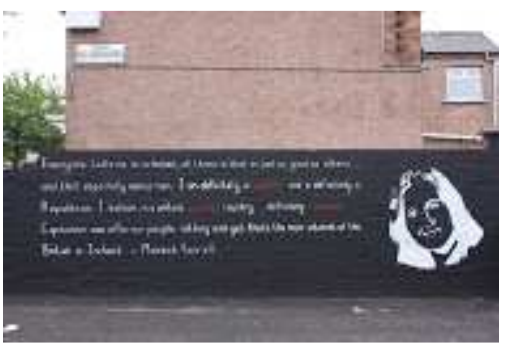

75. Socialist Republicanism, Berwick Road, Ardoyne, 2013

Other Republican murals are slightly less opaque and some suggest a degree of ambivalence towards support for a return to violence. One example is the Republican Network for Unity mural in the New Lodge that contains a reference to 'Belfast Brigade ONH' (Óglaigh nah Éireann, an armed Republican dissident group) (fig.76). While another, also in New Lodge, features the 32 County Sovereignty movement (though it publicly denies the accusation, the 32 CSM is often linked to the Real IRA, another armed Republican grouping) (fig. 77).

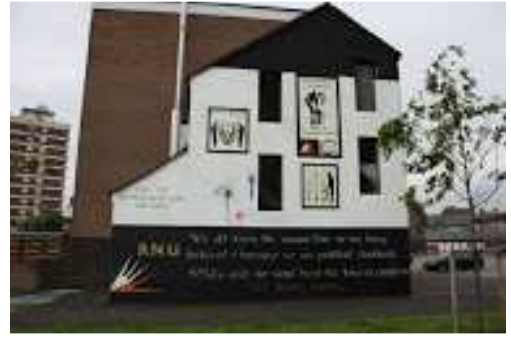

76. RNU, New Lodge Road, Belfast, 2014

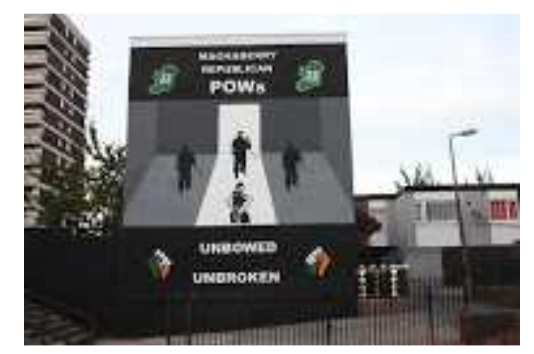

77. 32CSM, North Queen Street, New Lodge, 2014

19. 'The People's Gallery' is a set of murals on Rossville Street painted between 1994-2008 by the Bogside Artists, a non-aligned group of three muralists from Derry. See http://www.bogsideartists.com. 
In other wall-texts, however, there is no doubt about the threat of violence, as in a Continuity IRA mural on the Drumbeg estate in Lurgan (fig.78).

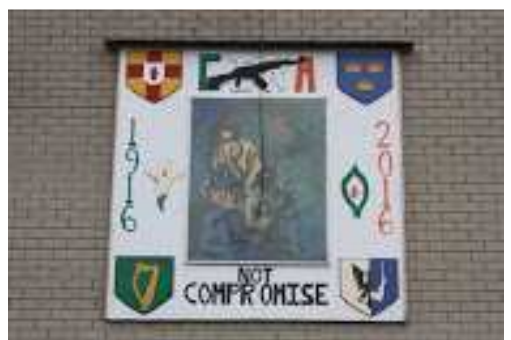

78. CIRA, Drumbeg, Drumbeg Estate, Lurgan, 2013

In these last examples, as in the Loyalist murals of the West Winds estate, there is little promise of peace or progress. Indeed, such has been the failure to address sectarian division within Northern Ireland, that there are now clear signs of retrenchment with the result that some of the advances that had been achieved have begun to be dismantled. One of the consequences of that development in relation to the murals is that texts that had presented alternative images have now been replaced by works that reflect the old, familiar, stark social antinomies. Thus in Mervue Street, in Tiger's Bay, one of a relatively small number of Loyalist murals that featured a woman (figs.79, 80),

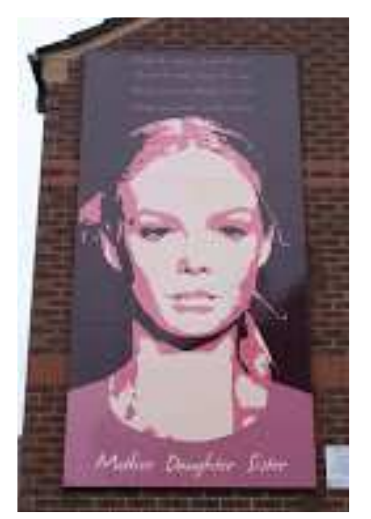

79. Mother Sister daughter (1), Mervue Street, Tigers Bay, Belfast, 2009

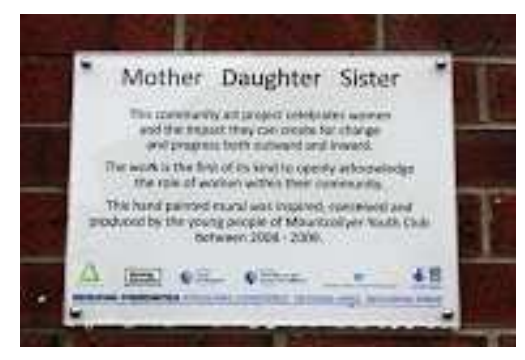

80. Mother Sister daughter (2), Mervue Street, Tigers Bay, Belfast, 2009

(and one of the smaller number that featured a woman without a gun fig.81), which only appeared in 2009, has recently been replaced by a more traditional representation (fig.82).

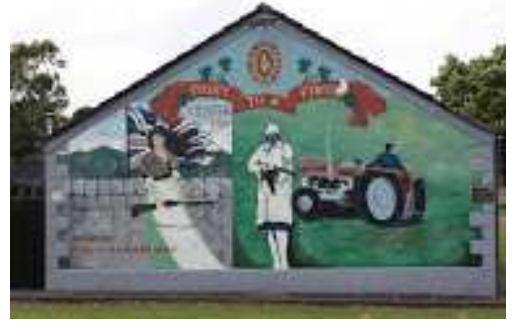

81. Women and guns, Drumtara, Ballymena, 2005

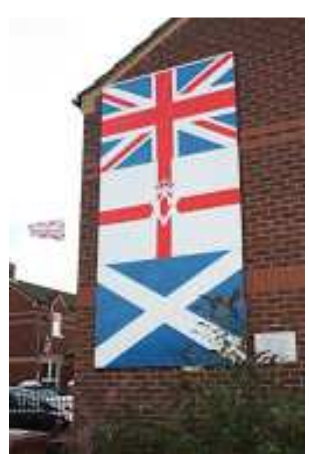

82. Back to Flags, Mervue Street, Tigers Bay, Belfast, 2014 
While at the entrance to the same area, a community mural ('Sport Music Peace Education Culture Community Diversity') (fig.83) has been supplanted by the familiar assertion/warning 'You're Entering Loyalist Tiger's Bay' (fig.84).

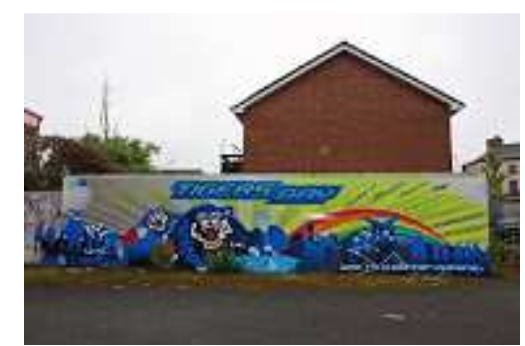

83. Community mural, North Queen St, Tigers Bay, Belfast, 2010

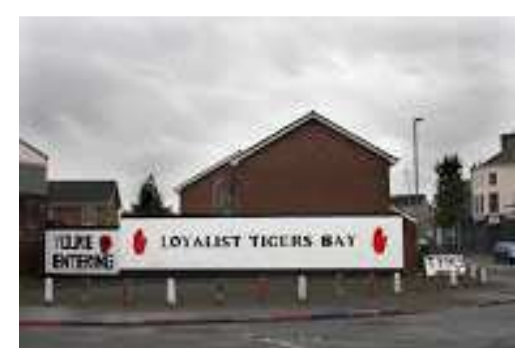

84. You're Entering Loyalist Tigers Bay, North Queen St, Tigers Bay, Belfast, 2014

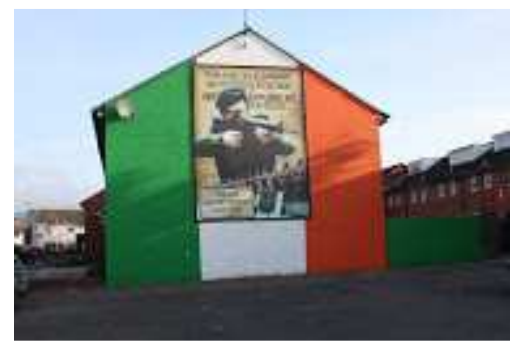

85. Martin Meehan, Ardoyne Avenue, Ardoyne, Belfast, 2014

The same type of process is also occurring in particular Republican areas. In Ardoyne, for example, the representation of a significant moment in the history or Gaelic culture (The Flight of the Earls), noted earlier (fig.25), has been changed for a mural commemorating Martin Meehan, local IRA commander, complete with rifle, against a backdrop of the Proclamation of the Irish Republic and a Tricolour (fig.85).

\section{Conclusion}

What then is the latest from the walls? My argument is that if read carefully, and contextually, the walls are telling us what they've always told us. Which is to say that distorted and caricatured as they sometimes are, the words and images on the walls give an insight into social realities that are often obscured by the niceties and imprecisions of other forms of discourse. Of course, as is evident from some of the analyses presented above, sometimes the walls need a lot of interpretation. What, for example, does it mean when, as happened last year, a long-standing mural about history, knowledge and power (fig.24), sited in a proudly Republican community, is replaced by a Sinn Féin-sanctioned work that appears to be curiously individualist and, at best, vaguely utopian (fig.86) ('I can't change the world, but I can change the world in me... All the stolen voices will one day be returned')? This particular work is somewhat baffling, and the general message from the walls seems mixed, but there are trends that clearly reflect growing concern about the failure of the new political order and the consequences that appear to be attending it. Evidently, as a number of new murals tell us, the threat of a return to organised political violence is a possibility, even if it remains unlikely at present. There are other murals, however, which present different possibilities and articulate important social insights. One such text presents a lesson about the historical reality of the social conditions and treatment of both the Catholic and Protestant working class whose importance may well be needed to gain widespread recognition if the future is to be transformed in productive ways (fig.87).

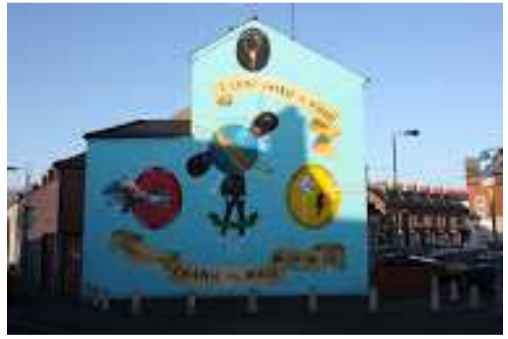

86. Change the World, Oakman Street, Beechmount, Belfast, 2014

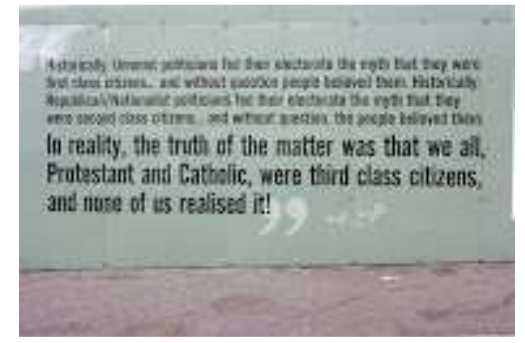

87. Citizens, Canmore Street, Shankill Road, Belfast, 2014 
But it is perhaps a sign of the contradictory and unstable nature of the present situation that this call for a class perspective in Northern Irish politics is articulated on a wall in a working-class Loyalist area that commemorates a politician, Hugh Smyth, who once led the Progressive Unionist Party. The PUP of course is closely associated with the Ulster Volunteer Force, an organisation whose recent murals, as noted above, not only serve to act as reminders of the brutal past, but as harbingers of a potentially violent future.

Received $4^{\text {th }}$ February 2015 Last version $21^{\text {st }}$ February 2015

Tony Crowley is a Chair of English at the University of Leeds and former Visiting Professor at the Institute of Irish Studies in Liverpool. He has published widely in the area of language and cultural theory, including Wars of Words: The Politics of Language in Ireland 1537-2004 (Oxford 2005) and Scouse: A Social and Cultural History (Liverpool 2012). He also curates the Murals of Northern Ireland Collection at the Claremont Colleges Digital Library. 